\title{
USING ARTIFICIAL NEURAL NETWORKS IN FINANCIAL FAILURE PREDICTION: AN APPLICATION IN BORSA ISTANBUL
}

DOI: 10.17261/Pressacademia.2021.1375

JEFA- V.8-ISS.1-2021(3)-p.17-30

Mehmet Nuri Salur

Necmettin Erbakan University, Faculty of Political Science, Department of Business Administration, Konya, Turkey. nsalur@erbakan.edu.tr, ORCID: 0000-0003-1089-1372

\begin{tabular}{l} 
Date Received: January 14, $2021 \quad$ Date Accepted: March 15, 2021 \\
\hline To cite this document \\
Salur, M. N. (2021). Using artificial neural networks in financial failure prediction: an application in Borsa Istanbul. Journal of Economics, \\
Finance and Accounting (JEFA), V.8(1), p.17-30. \\
Permanent link to this document: $\underline{\text { http://doi.org/10.17261/Pressacademia.2021.1375 }}$ \\
Copyright: Published by PressAcademia and limited licensed re-use rights only.
\end{tabular}

\section{ABSTRACT}

Purpose - Financial failure causes to negative effects upon not only life course of enterprises but also a great number of stakeholders such as owner or partners of an enterprise, government, investor, institutions and organizations providing the enterprise with credit. Together change in information and communication technologies, in financial failure prediction studies the place of artificial intelligence applications is increasingly. Objective of this study is to develop a model -with artificial neural networks that is one of the artificial intelligence applicationsregarding to estimating financial situations by benefiting from financial statements (tables) of enterprises being traded at Borsa İstanbul, Turkey and to measure estimation competency of this developed model.

Methodology - Within the context of the study, an estimation model was developed on the basis of financial statements.

Findings- Sample was classified into two sub-groups as training set and test set in the model, in which one-year-before-failure financial statements of enterprises, which failed financially, were benefited. Afterwards estimation competency of the network, which was trained with training set, was measured through test set.

Conclusion- In conclusion, according to obtained findings, it was observed that the model artificial neural networks delivered a high performance in estimating financial failure over selected sample.

Keywords: Financial failure, bankruptcy, artificial neural network, prediction model, Borsa Istanbul JEL Codes: M10, M40, G33

\section{FINANSAL BAŞARISIZLIK TAHMININDE YAPAY SINIR AĞLARI MODELININ KULLANIMI: BORSA ISTANBUL'DA BIR UYGULAMA}

\section{ÖZET}

Amaç - Finansal başarısızlık hem işletmelerin hayat seyirleri üzerinde hem de işletmenin sahip veya ortakları, devlet, yatırımcı, işletmeye kredi sağlayan kurum ve kuruluşlar gibi çok sayıda paydaş üzerinde olumsuz etkilere neden olmaktadır. Finansal başarısızlık tahmin çalışmalarında günümüzde bilgi ve iletişim teknolojilerinde yaşanan değişimle birlikte yapay zekâ uygulamalarının yeri gittikçe artmaktadır. Bu çalışmanın amacı, yapay zekâ uygulamalarından biri olan yapay sinir ağları ile Türkiye'de Borsa İstanbul'da işlem gören işletmelerin finansal tablolarından yararlanarak finansal durumlarının tahmin edilmesine yönelik bir model geliştirmek ve geliştirilen bu modelin tahmin gücünü ölçmektir. Yöntem - Çalışma kapsamında, işletmelerin finansal tablo verileri üzerinde, yapay sinir ağları kullanılarak tahmin modeli geliştirilmiştir. Bulgular- Finansal başarısız olan işletmelerin başarısızlıktan bir yıl önceki finansal tablo verilerinin kullanıldığı modelde örneklem, eğitim seti ve test seti olmak üzere iki alt kümeye ayrılmıştır. Sonrasında ise eğitim seti ile eğitilen ağın test seti üzerinden tahmin gücü ölçülmüştür. Sonuç- Sonuç olarak, elde edilen bulgulara göre, yapay sinir ağları modelinin seçilen örneklem üzerinde finansal başarısızlığı tahmin etmede yüksek bir performans gösterdiği görülmüştür.

Anahtar Kelimeler: Finansal başarısızlık, iflas, yapay sinir ağları, tahmin modeli, Borsa İstanbu JEL Kodları: M10, M40, G33

\footnotetext{
* Bu çalışma, "İşletmelerde Finansal Başarısızlık Tahmini ve Yapay Sinir Ağları Modelinin Kullanımı: Borsa İstanbul'da Bir Uygulama" isimli doktora tezinden türetilmiştir.
} 


\section{GiRiş}

Hızla değişen ve gelişen küresel bir dünyada işletmelerin sürdürülebilir rekabet şartlarını yerine getirebilmesi ve yaşamlarını devam ettirebilmesi için özellikle bilgi teknolojilerinde değişime uyum sağlaması gerekmektedir. Zira rekabetin hızla arttığı, ülkeler arası sınırların kalktığı ve bilgiye ulaşma hızının neredeyse anlık olduğu bir dünyada ticaret anlayışının değişmesi de kaçınılmaz olmuştur. Dolayısıyla bu yeni dönemin şartlarına uyum sağlayamayan, işletme içi veya işletme dışı faktörler nedeniyle rekabete karşı direnemeyen işletmeler başarısızlığa uğramakta ve hatta sonu iflas ve tasfiyeye kadar giden bir süreçle yüzleşmek zorunda kalabilmektedir.

İşletmelerin başarısızığa uğramaları sadece kendi paydaşlarına değil aynı zamanda ülke ekonomilerine de ciddi maliyetler yüklemektedir. Zira bir ülke ekonomisinde başarısız işletmelerin sayısındaki artış, istihdam ve refah düzeyi ile ilgili olumsuz sonuçlara neden olacaktır. Bu açıdan bakıldığında işletmelerdeki başarısızlığın etkilerinin sadece mikro düzeyde değil aynı zamanda tüm toplumu etkileyen sosyo-ekonomik bir kavram olarak makro düzeyde de ele alınması gerekmektedir.

İşletmelerin maruz kalabileceği başarısızıı kavramı en basit ifadeyle yükümlülüklerini yerine getirememesi olarak ifade edilebilir. Bu kapsamda temel amacı büyüme ve kâr elde etmek olan işletmeler için en önemli yükümlülüklerinin ise finansal yükümlülükler olduğunu ifade etmek yanlış olmayacaktır. Dolayısıyla işletmelerdeki başarısızlık kavramını bu açıdan değerlendirecek olursak başarısızlığın en önemli nedenleri arasında finansal yükümlülüklerin yerine getirilememesi olduğu ve bunun da işletmeleri finansal başarısızlığa sürüklediği görülmektedir.

Bir işletmenin finansal durumunu önceden tahmin ederek finansal başarısızlığa engel olunabilmesi için işletmeyi finansal başarısızlığa sürükleyebilecek iç ve dış faktörlerin ilgili departmanlar tarafından zamanında belirlenmesi ve doğru önlemleri içeren bir model geliştirilmesi çok büyük oranda olumlu katkı sağlayacaktır. Zira böyle bir model işletme sahip ve yöneticileri için başarısızığa karşı erken uyarı sistemi görevi görerek zamanında ve önleyici tedbirlerin alınması için önemli bir araç olacaktır. Ayrıca böyle bir model potansiyel yatırımcılar ve kredi verenler gibi diğer işletme paydaşları açısından da önemli bir değerlendirme aracı olacaktır.

Finansal başarısızlık tahmini muhasebe ve finans bilimi için yıllardır önemini korumaktadır. Bu nedenledir ki finansal başarısızık konusunda yapılan bilimsel çalışmalar yıllar itibariyle artmakta, sürekli yeni ve farklı yöntemler kullanılarak tahmin modellerinin geliştirilmesine çalışılmaktadır.

Finansal başarısızık tahmininde yapılan ilk çalışmalar tek bir finansal oranın kullanıldığı tek değişkenli istatistiki modeller olmuştur. Ancak tek bir finansal oranın kullanıldığı bu tek değişkenli modellere getirilen eleştirilerle birlikte sonraki yıllarda birden fazla finansal oran kullanılarak geliştirilen çok değişkenli istatistiki modeller ortaya çıkmıştır. Daha sonraki ilerleyen yıllarda ise özellikle bilgi teknolojilerindeki gelişmelerin de etkisiyle, insan beynini taklit ederek insanlar gibi karar verebilen yapay zekâ teknolojileri ile erken uyarı sistemleri bambaşka bir boyuta evrilmiştir. Yapay sinir ağları, bulanık mantık, uzman sistemler, genetik algoritmalar gibi farklı isimlerle adlandırılan yapay zekâ uygulamaları günümüzde farklı alanlardaki farklı problemlerin çözümünde yaygın olarak kullanılmakla birlikte finansal başarısızlık tahmin çalışmalarında da başarıyla uygulanmaktadır. Yapay zekâ teknolojileri içerisinde yer alan ve çalışmamızda da kullandığımız yapay sinir ağları insan beynini taklit ederek insani karar verme yetisinin bilgisayar sistemlerince gerçekleştirildiği bir makine öğrenmesidir. Yapay sinir ağlarının finansal başarısızlık tahmin çalışmalarında kullanımı matematiksel ve istatistiksel modellerin kısıtlayıcı sınırlarını ortadan kaldırdığı için bu alanda önem kazanmış ve yıllar itibariyle de daha çok kullanıımasının önünü açmıştır.

Çalışmada, öncelikle finansal başarısızlık kavramı literatürdeki farklı tanımlamalar da dikkate alınarak açıklanmış ve bu kapsamda çalışmamızın finansal başarızlık kriterlerini belirleyen ölçütler ifade edilmiştir. Daha sonra ise yapay sinir ağları kavramı ele alınmıştır. Çalışmamızın üçüncü bölümünde finansal başarısızık alanında yapay sinir ağlarının kullanıldığı çalışmalarla ilgi literatür taramasına yer verilmiştir. Dördüncü bölümde, Borsa İstanbul'da işlem gören firmalar üzerine yapay sinir ağları modelinin kullanıldığı bir finansal başarısızık tahmin modeli geliştirilmiş ve bu kapsamda veri setinin özellikleri, modelde kullanılan bağımsız değişkenler ve modelin geliştirilme aşamaları açıklanmıştır. Beşinci bölümde ise, uygulama bulguları üzerinden yapılan değerlendirmeye yer verilmiştir.

\section{FINANSAL BAŞARISIZLIK VE YAPAY SINIR AĞLARI}

\subsection{Finansal Başarısızlık Kavramı}

Temel amacı kâr elde etmek olan ve teorik olarak ömrü sınırsız kabul edilen işletmeler genel olarak kuruldukları ilk yıl veya daha sonraki yıllarda başarısızlıkla karşı karşıya kalmaktadırlar. Bazı işletmeler ise zaman içerisinde büyüyerek tüm paydaşlarını memnun edecek bir gelişme seyri izleyebilirler (Gitman ve Chad, 2011:737). Ancak bu durum nasıl ki kurulan her işletmenin kuruluşunun hemen akabindeki yıllarda başarısızlık riskini atlatmasına rağmen sınırsız kabul edilen ömrü içerisinde bir daha başarısızlığa uğramayacağı anlamına gelemezse uzun yıllar başarılı bir şekilde faaliyetini yürüten işletmelerin de yıllar içerisinde finansal açıdan başarısız olabilecekleri gerçeğini değiştirmeyecektir. 
İşletmelerde başarısızık, farklı şekillerde ortaya çıkabilir. Bir işletmenin başarııılığı, geçici nedenlerle mali yükümlülüklerini karşılayamamasından işletme varlıklarının tasfiye edilmesiyle iflasa kadar uzanan durumları içeren bir süreci ifade eder (Akgüç, 2010:947). İşletmelerde farklı şekillerde ortaya çıkan başarısızlık genellikle bir süreç olarak hem ekonomik hem de finansal olarak ortaya çıkmaktadır (Moyer vd., 2011:837). Bu kavramlar birbirinden farklı olmamakla birlikte ekonomik başarısızlık kavramının sınırları ise daha belirsizdir.

Finansal başarısızık ve finansal başarısızlık tahminine yönelik çalışmalar son kırk yıl yılda önem kazanmış olmasına rağmen finansal başarısızlık kavramıyla ilgili finans literatüründe genel kabul görmüş ortak bir tanım olmadığı görülmektedir.

Finansal başarısızlık konusunda ilk çalışmalardan birini yapan Beaver (1966) finansal başarısızlığı bir işletmenin vadesi gelmiş finansal yükümlülüklerini karşılayamaması olarak ifade etmiştir (Beaver, 1966:71). Diğer bir ifadeyle bu durum işletmenin borçlarını ödeyememesi durumu olarak da ifade edilebilir. Ross vd. (2008)'e göre finansal başarısızlık; işletme faaliyetlerinden elde edilen nakit akışları ile işletmenin finansal yükümlülüklerinin ve taahhütlerinin yerine getirilememesi ve işletmenin bu sıkıntıları aşmak için birtakım önlemler almaya zorlanması durumu olarak ifade edilmiştir (Ross vd., 2008:411).

Tablo 1: Literatürdeki Finansal Başarısızlık Tanımları

\begin{tabular}{|c|c|c|c|}
\hline Araştırmacı & $\begin{array}{l}\text { Araştırmanın } \\
\text { Tarihi }\end{array}$ & $\begin{array}{l}\text { Finansal Başarısızlığı } \\
\text { Nasıl Tanımladığı }\end{array}$ & e \\
\hline Beaver & 1966 & Başarısızlık & $\begin{array}{l}\text { Vadesi gelen finansal yükümlülükleri karşılayamama. } \\
\text { Başarısızlık tanımı içinde kabul edilen olaylar ise; tahvil } \\
\text { faizlerinin ödenememesi, karşılıksız çek düzenlenmesi, } \\
\text { imtiyazılı hisse senetlerine temettü dağıtılmaması. }\end{array}$ \\
\hline Altman & 1968 & iflas & $\begin{array}{l}\text { Yasal olarak iflas başvurusunda bulunmuş olma ve } \\
\text { kayyum atanmış ya da ulusal iflas yasası hükümlerince } \\
\text { reorganizasyon hakkı verilmiş işletmeler. }\end{array}$ \\
\hline Wilcox & 1971 & Başarısızlık & $\begin{array}{l}\text { Belirlenen iki nokta arasında işletmenin varlıklarında } \\
\text { meydana gelen azalma. }\end{array}$ \\
\hline Edminister & 1972 & Başarısızlık & Beaver (1966) ile aynı kriterleri kullanmıştır. \\
\hline Blum & 1974 & Başarısızlık & $\begin{array}{l}\text { Vadesi gelen borçların zamanında ödenememesi, } \\
\text { alacaklılar ile borçların azaltılması konusunda anlaşma } \\
\text { talebinde bulunma ve iflas sürecine girme. }\end{array}$ \\
\hline Elam & 1975 & Iflas & $\begin{array}{l}\text { Toplam yükümlülüklerin toplam varlıkların gerçeğe uygun } \\
\text { değerini aşması, ulusal iflas yasası hükümlerince } \\
\text { reorganizasyon hakkı }\end{array}$ \\
\hline Deakin & 1976 & Başarısızlık & $\begin{array}{l}\text { İflas etme veya alacaklıların isteği üzerine tasfiye sürecine } \\
\text { girme. }\end{array}$ \\
\hline Altman vd. & 1977 & Iflas & Yasal olarak iflas başvurusunda bulunmuş olmak. \\
\hline $\begin{array}{l}\text { Van- } \\
\text { Frederikslust }\end{array}$ & 1978 & Başarısızlık & $\begin{array}{l}\text { Borçlarını zamanında ödeyemeyerek teknik olarak nakit } \\
\text { acziyetine düşmek }\end{array}$ \\
\hline $\begin{array}{l}\text { Norton ve } \\
\text { Smith }\end{array}$ & 1979 & İflas & Beaver (1966) ve Elam (1975) ile aynı kriteri kullanmıştır. \\
\hline $\begin{array}{l}\text { Dambolena } \\
\text { ve Khoury }\end{array}$ & 1980 & Başarısızlık & Altman (1968) ile aynı kriterleri kullanmıştır. \\
\hline Ohlson & 1980 & íflas & Yasal olarak iflas başvurusunda bulunmuş olmak. \\
\hline Zavgren & 1982 & Iflas & Yasal olarak iflas başvurusunda bulunmuş olmak. \\
\hline Taffler & 1982 & Başarısızlık/iflas & $\begin{array}{l}\text { Tasfiye, alacaklıların isteği üzerine tasfiye ve mahkeme } \\
\text { kararıyla faaliyete son vermiş olmak. }\end{array}$ \\
\hline Zmijewski & 1983 & iflas & Yasal olarak iflas başvurusunda bulunmuş olmak. \\
\hline $\begin{array}{l}\text { Casey ve } \\
\text { Bartczak }\end{array}$ & 1985 & Iflas & Yasal olarak iflas başvurusunda bulunmuş olmak. \\
\hline Aktaş & 1993 & Başarısızlık & $\begin{array}{l}\text { Üç yıl üst üste zarar etmiş olma veya yaşanan mali kriz } \\
\text { nedeniyle üretimin durdurulması. }\end{array}$ \\
\hline Beaver vd. & 2009 & Iflas & $\begin{array}{l}\text { Bir yıl içerisinde yasal olarak iflas başvurusunda bulunmuş } \\
\text { olmak. }\end{array}$ \\
\hline Wu vd. & 2010 & İflas & $\begin{array}{l}\text { Bir yıl içerisinde yasal olarak iflas başvurusunda bulunmuş } \\
\text { olmak. }\end{array}$ \\
\hline
\end{tabular}




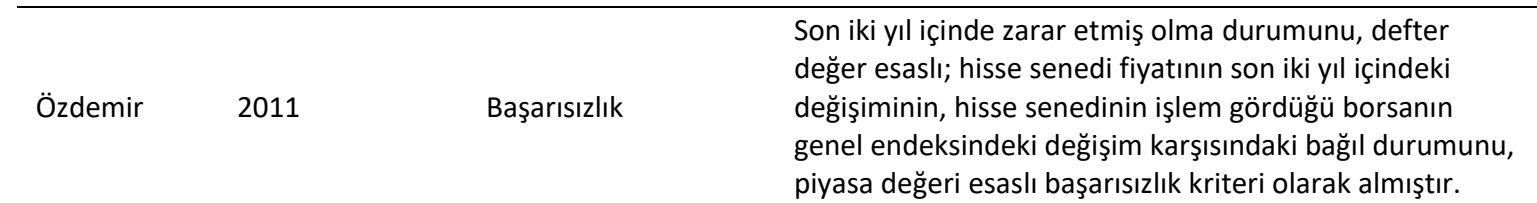

Kaynak: Özdemir, F. S., Choi, F. S. ve Bayazıtlı, E. (2012). Finansal Başarısızlık Tahminleri Yönüyle UFRS ve Bilginin İhtiyaca Uygunluğu, Mali Çözüm Dergisi, 112, 17-52'den uyarlanmıştır.

Tablo 1 incelendiğinde literatürde yer alan çalışmaların birçoğunda finansal başarısızlık durumu olarak iflasın kabul edildiği görülmektedir. Iflasa göre daha esnek bir tanım olan finansal başarısızık, işletmelerin karşılaştıkları farklı durumlara göre farklı şekillerde tanımlanmaktadır. Finansal başarısızlığın farklı tanımları, araştırmalarda örneklem içerisine girecek başarısız işletme sayısının değişmesine neden olacağı için bu alanda yapılan çalışmalar da doğrudan etkilenmektedir.

Çalışmalarda finansal başarısızlık teriminin kullanılması, özellikle gelişmekte olan ülkelerdeki araştırmaların yürütülmesinde birtakım kolaylıklar sağlamaktadır. Zira finansal başarısızık durumu olarak iflası seçen çalışmaların yoğunlukla ve görece gelişmiş ülkelerde yapılmış olduğu görülmektedir. Çünkü bu ülkelerde gelişmekte olan ülkelere göre hem yeterli sayıda iflas etmiş işletme örneğine rastlanmakta hem de bu işletmelere ait güvenli bir veri seti elde etme noktasında pek fazla bir sorunla karşılaşılmamaktadır (Özdemir vd., 2012:28). Gelişmekte olan ülkelerde iflasa kıyasla esnek bir tanım olan finansal başarısızlığın seçilmesi, araştırma örneğinin daha geniş tutulmasına imkân tanımaktadır. Ayrıca finansal başarısızlık teriminin kullanılması kuramsal açıdan da üstünlük taşımaktadır. Finansal sıkıntı içerisinde bulunan işletmeleri finansal başarısızlık kavramı içerisine dahil etmenin pragmatik sonuçları sadece iflas etmiş işletmeleri örneklem içerisine dahil etmenin pragmatik sonuçlarından daha fazladır. Çünkü finansal sorunları olan her işletme iflas etmemektedir. Iflas, finansal sorunları çözemeyen işletmeler için son çaredir (Torun, 2007:7). Bir başka deyişle, finansal başarısızlık bir süreç, iflas ise zamanında ve gerekli tedbirler alınmayarak başarısız yürütülen bu sürecin bir sonucudur.

Bu çalışmada da tüm anlatılanlar ışığında, işletmelerin içinde bulundukları finansal sıkıntıları tanımlamak için "finansal başarısızıı" kavramının kullanılması tercih edilmiştir. Bu çalışmada tüm iç ve dış bilgi kullanıcıları açısından iflastan önceki finansal başarısızlık durumlarını öngörmenin sağlayacağı yararlar dikkate alınarak finansal başarısızlık kriteri olarak aşağıda belirtilen ölçütler dikkate alınmıştır:

1. İşletmenin en az iki yıl üst üste zarar etmiş olması,

2. Borsa İstanbul'daki işlem sırasının kapanması,

3. Borsa İstanbul'da kottan çıkarılma veya gözaltı pazarına alınması,

4. İşletmenin aktif büyüklüğünün bir önceki yıla göre en az \%10 azalması,

5. İşletmenin özkaynaklarının bir önceki yıla göre en az \%10 azalması,

6. Sermayesinin yarısının veya 2/3'ünün kaybolması,

7. Net işletme sermayesinin negatif olması.

Yukarıdaki ölçütlerden herhangi birine uyan işletmeler "başarısız" olarak kabul edilmiştir. Bu kriterlere uymayan işletmeler ise "başarılı" olarak kabul edilmiştir.

\subsection{Yapay Sinir Ağları}

Illeriye yönelik tahmin çalışmalarında geleneksel tahmin yöntemlerine alternatif olarak kullanılan yapay zekâ yöntemlerinden biri de yapay sinir ağlarıdır (Zhang vd., 1998:35). Yapay sinir ağları, tahvil dereceleme, hisse senedi fiyatlarının yönü, finansal sıkıntı tespiti, kredi değerliliğinin belirlenmesi, banka başarısızlıklarının tahmini ve iflas tahmini gibi finansal alanlarda da başarıyla kullanılmaktadır (Gritta vd., 2000:45).

Yapay sinir ağları, insan beyninin özelliklerinden olan öğrenme yolu ile yeni bilgiler türetebilme, yeni bilgiler oluşturabilme ve keşfedebilme gibi yetenekleri herhangi bir yardım almadan otomatik olarak gerçekleştirmek amacı ile geliştirilen bilgisayar sistemleridir (Öztemel, 2012:29).

Yapay sinir ağı kavramı insan beyninin çalışma ilkelerinin sayısal verilere dönüştürülerek bilgisayarlar yardımıyla taklit edilmesi fikri olarak ortaya çıkmış ve ilk çalışmalar beyni oluşturan biyolojik hücrelerin ya da literatürdeki ismi ile nöronların matematiksel olarak modellenmesi üzerinde yoğunlaşmıştır (Efe ve Kaynak, 2000:1).

Yapay sinir ağı, nörofizyologların ve psikologların çalışmalarından elde edilen sonuçlardan yararlanarak, insan beynindeki sinir ağlarının yapısal ve işlevsel özelliklerinin basite indirgenip matematiksel olarak modellenmesidir (Küçükkocaoğlu vd., 2009:8). 
Yapay sinir ağları çok değişkenli ve değişkenler arasında karmaşık, karşılıklı etkileşimin bulunduğu veya tek bir çözüm kümesinin bulunmadığı durumlarda başarılı sonuçlar üreten bir yapay zekâ teknolojisidir (Aktaş vd., 2003:7).

Yapay sinir ağları her biri sürecin bir parçası ve birbiriyle bağlantılı nöronlardan oluşan, biyolojik sinir ağlarının fonksiyonları modellenerek geliştirilmiş sistemlerdir (Alavala, 2008:121).

Yapay sinir ağları, sinir hücreleri arasında ilişki kuran, belli bir fonksiyonla bu ilişkilerden sonuçlar üreten ve bu sonuçları örneklerle karşılaştırarak optimize eden bir sistemdir (Fausett, 1994:5).

Yapay sinir ağları, birbirine paralel olarak faaliyet gösteren ve doğrusal olmayan hesaplamalı elemanlardan oluşan, aynı zamanda biyolojik sinir ağlarını andıran modellerdir (Lippmann, 1987:4):

\section{LITERATÜR TARAMASI}

Finans alanında yapay sinir ağlarının kullanımı 1990'lı yılların sonuna doğru artmaya başlamıştır. Finans alanıyla ilgili problemlerin veri yoğunluğu, belirsizliğin yüksek olması, değişkenler arasında kolay standartlaştırılamayan gizli ilişkilerin varlığı gibi özellikleri yapay sinir ağlarını bu alanda kullanmayı uygun hale getirmiştir. Yapay sinir ağları sınıflandırma ve regresyon amaçlı kullanıldıkları için finansal başarısızlık alanında kullanımı da bir öngörü modellemesi olmakla birlikte aslında başarı ve başarısızlık durumlarının sınıflandırılmasıdır. Yapay sinir ağlarının kullanıldığı birçok farklı finansal alanda olduğu gibi finansal başarısızlık alanındaki uygulamalarında da geleneksel istatistiki yöntemlere oranla daha iyi ve daha doğru sonuçlar verdiği gözlemlenmiştir (Tektaş ve Karataş, 2004:343).

Yapay sinir ağları doğrusal olmayan problemlere uygulanan bir modelleme aracı olduğu için finansal uygulamalarda bağımlı ve bağımsız değişkenler arasındaki doğrusal olmayan ilişkilerde başarıyla uygulanmaktadır (Yıldız, 2009:108). Bu kapsamda yapay sinir ağları modeli kullanılarak yapılan finansal başarısızlık tahmin çalışmalarında da başarılı sonuçlar alındığı görülmektedir.

Yapay sinir ağları ile yapılan ilk finansal başarısızlık tahmin çalışması 1990 yılında Odom ve Sharda tarafından yapılmıştır. Odom ve Sharda (1990) tarafından yapılan çalışmada 1975-1982 yılları arasındaki 65 başarısız firma ve 64 başarılı firma olmak üzere toplam 129 firmadan oluşan bir örneklem oluşturulmuştur. Model oluşturulurken bağımsız değişken olarak Altman'ın Z-skor modelindeki beş finansal oran seçilirken ağ mimarisi de geri yayılım algoritması kullanan bir yapay sinir ağı olarak belirlenmiştir. Seçilen finansal oranlar finansal başarısız firmaların başarısızlıktan önceki son yıllarına ait finansal tablolarından elde edilmiştir. Model oluşturulurken örneklem eğitim seti ve test seti olarak ayrıımıştır. Çalışmanın sonucunda ise yapay sinir ağları ile oluşturdukları model ile finansal başarısız olan firmalar \%81,48 oranında doğru tahmin edilmiştir.

Raghupathi vd. (1991), 51 başarısız ve 51 başarılı olmak üzere eşit sayıda belirledikleri toplam 102 firma ile bir yapay sinir ağı modeli oluşturmuş ve elde ettikleri sonucu da bir tebliğde sunmuşlardır. Çalışmada ağ mimarisi olarak geri yayılım algoritması kullanan bir ağ seçilmiş ve oluşturulan modelin finansal başarısızık tahmini için doğru sonuçlar verdiği görülmüştür.

Pompe ve Feelders (1996), yaptıkları çalışmada Belçika'da faaliyet gösteren iki farklı sektörden toplam 1.500 firmanın finansal başarısızlık durumlarını finansal oranlar yardımıyla tahmin etmeye çalışmıştır. Çalışmada yapay sinir ağları, diskriminant analizi ve regresyon ağaçları kullanılmış ve çalışma sonucunda ise yapay sinir ağları modelinin her iki sektör için de daha başarılı bir tahmin modeli olduğu görülmüştür.

Jo vd. (1997), tarafından yapılan çalışmada Kore'de 554 firmalı bir örneklem üzerinde finansal başarısızlık tahmini yapılmıştır. Çalışmada yapay sinir ağları, diskriminant analizi ve case-based tahmin sistemleri kullanılmıştır. Çalışma sonucunda yapay sinir ağları ile geliştirilen modelin diğer sistemlerden daha üstün olduğu görülmüştür

Zhang vd. (1999), yaptıkları çalışma ile 1980 ile 1991 yılları arasında Amerika'da NASDAQ Borsası'nda faaliyet gösteren üretim firmalarından oluşturdukları bir örneklem ile lojistik regresyon analizi ile yapay sinir ağları modelinin iflas tahminindeki doğru sınıflandırma derecesini karşılaştırmışlardır. Altman'ın beş finansal oranını kullanarak geliştirdikleri her iki modelle yapılan çalışmada yapay sinir ağları ile oluşturdukları modelin diğer modele göre daha başarılı bir sınıflandırma yaptığı sonucuna ulaşmışlardır.

Atiya (2001), tarafından yapılan çalışmada iflasın 1-36 ay öncesinden tahmin edilebilmesi amacıyla yapay sinir ağlarını kullanan modeller geliştirilmiştir. Araştırma örneklemi olarak 1.160 firmanın belirlendiği çalışmada yapay sinir ağlarıyla oluşturulan modellerin doğru öngörüde bulunduğu görülmüştür.

Yıldız (2001), iMKB'de 1983-1997 yılları arasında işlem gören 106 firmadan oluşturduğu örneklem ile yaptığı çalışmasında firmaları yapay sinir ağları ile başarısız ya da başarısız olmayan işletmeler olarak tahmin etmiştir. Bağımsız değişken olarak firmaların tablolarından elde edilen 15 finansal oranın kullanıldığı çalışmada yapay sinir ağları sonuçları ile ayırma analizi sonuçlarını karşılaştırmıştır. Çalışma sonucunda yapay sinir ağlarının \%94,40 gibi yüksek bir oranda doğru tahminde bulunduğunu tespit etmiştir. 
Keskin (2002), 1992-2002 yılları arasında iMKB'de işlem gören firmalardan oluşturduğu örneklem ile işletmelerdeki finansal başarısızlık ya da başarı durumlarını 1, 2 ve 3 yıl önceden tahmin etmeye çalışmıştır. Toplam 142 firma üzerinde yapılan araştırmada çoklu diskriminant analizi, lojistik regresyon analizi ve yapay sinir ağları modelleri kullanılmış ve bu modellerin tahmin performansları karşılaştırılmıştır. Bağımsız değişken olarak finansal oranların kullanıldığı çalışma sonucunda yapay sinir ağları ile oluşturulan tahmin modelinin daha yüksek oranda tahmin gücüne sahip olduğu gözlemlenmiştir.

Aktaş vd. (2003), yaptıkları çalışmalarında finansal başarısızlık tahmininde daha önce kullanılan çok boyutlu istatistiksel modellerle yapay sinir ağları modelini karşılaştırmışlardır. 1983-1997 yılları arasında iMKB'de işlem gören toplam 106 firmadan oluşturdukları örneklemi 53 başarısız ve 53 başarıı olmak üzere eşit sayıda gruplandırmışlardır. Örneklem üzerinde 23 farklı finansal oranı kullandıkları çalışma sonucunda yapay sinir ağları modeli ile \%86,11 oranında başarılı öngörüde bulunmuşlar ve bu oranın çalışmalarında kullandıkları diğer çok boyutlu istatistiksel modellerden çok daha yüksek olduğunu tespit etmişlerdir.

Nguyen (2005), mali tablolardan elde ettikleri finansal oranlar yardımıyla oluşturdukları çok katmanlı yapay sinir ağı modeli, olasılıklı yapay sinir ağı modeli ve lojistik regresyon modelini kullanarak işletmelerde finansal başarısızlığın tahmin edilebilme gücünü araştırmışlardır. Araştırma örneklemi 1988-2002 yılları arasında Avusturya'da faaliyet gösteren toplam 232 işletmeden oluşturulmuştur. Bu şirketlerden 32 tanesi araştırma için eğitim örneklemini oluştururken 200 tanesi de test örneklemini oluşturmaktadır. Çalışmanın sonunda olasılıklı yapay sinir ağı modelinin işletmelerdeki finansal başarısızlığı tahmin etmede diğer iki modelden daha başarılı olduğu görülmüştür.

Benli (2005), Türkiye'deki özel sermayeli bankaların finansal başarısızlığını 1 yıl önceden tahmin etmek için yapay sinir ağları ve lojistik regresyon analizi ile modelleme geliştirmiştir. Çalışmada başarısızlık kriteri olarak TMSF'ye devredilme kriteri belirlenmiş olup örneklem 1997-2001 yılları arasında TMSF'ye devredilen 17 banka ile faaliyetine devam eden 21 bankadan oluşturulmuştur. Bağımsız değişken olarak ise tek değişkenli varyans analizinden geçirilen 12 finansal oran kullanılmıştır. Çalışma sonucunda yapay sinir ağları modelinin bankalardaki finansal başarısızlığı tahmin gücü \%82,40 olarak bulunmuş ve lojistik regresyon analizinden daha başarılı bir performans gösterdiği tespit edilmiş̧ir.

Chen vd. (2006), firmaların finansal başarı ve başarısızlık durumlarını 2 yıl önceden tahmin edilebilirliğini araştırmak üzere 2003 yılında yapay sinir ağları, diskriminant analizi, lojistik regresyon analizi ve karar ağaçları yönteminin kullanıldığı modeller oluşturmuşlardır. Sonuçlara bakıldığında finansal başarısızlık tahminini en iyi yapan modelin 2001 yılına ait finansal oranları kullanan yapay sinir ağları modeli olduğunu tespit etmişlerdir.

Chakraborty ve Sharma (2007), yaptıkları çalışmada yapay sinir ağları ile finansal başarısızlık tahmin gücünü ölçmüşlerdir. Toplam 220 firmadan oluşan örneklemde 145 firma başarılı, 75 firma başarısız olarak tespit edilmiş ve finansal oranlar yardımıyla oluşturulan yapay sinir ağları modelinin başarılı ve başarısız firmaları 1, 2 ve 3 yıl önceden yüksek oranda doğru sınıflandırma yaptıkları görülmüştür.

Ravi ve Pramodh (2008), çalışmalarında İspanya ve Türkiye'de banka finansal başarısızıklarını tahmin etmeyi amaçlamışlardır. Yapay sinir ağları ile geliştirilen modelde örneklem olarak İspanya veri seti için 66, Türkiye veri seti için 40 banka belirlenmiş olup, bağımsız değişken olarak finansal oranlar kullanılmıştır. Çalışma sonucunda oluşturulan yapay sinir ağları modeli ile İspanya için \%96,60, Türkiye için ise \%100 oranında doğru tahmin gücü elde edilmiştir.

Wu vd. (2008), çoklu diskriminant analizi ve yapay sinir ağlarını kullanarak işletmelerin başarılı ve başarısız olma durumlarını öngörmeyi amaçlamışlardır. Çalışma örneklemi için Çin'de faaliyet gösteren 32 firma belirlenmiş ve bu firmalar başarıı ve başarısız olarak iki gruba ayrıımıştır. Bağımsız değişken olarak 7 farklı finansal oranı kullanarak geliştirdikleri her iki modelde de işletmelerin finansal açıdan başarısız olma durumlarının 1 yıl ve 3 yıl önceden tahmin edilmesi amaçlanmıştır. Çalışma sonucunda hem 1 yıl önceden hem de 3 yıl önceden yapılan tahminlerin başarı oranının yapay sinir ağlarında daha yüksek olduğu belirlenmiştir.

Akkaya vd. (2009), yaptıkları çalışmada Tekstil, Kimya Petrol ve Plastik sektöründe faaliyet gösteren firmaların finansal başarısızlıklarının bir yıl önceden tahmini için yapay sinir ağları ile geliştirdikleri modelin \%80 oranında doğru tahmin yaptığı sonucuna ulaşmışlardır.

Boyacıoğlu vd. (2009), Türkiye' de faaliyet gösteren bankalar için finansal başarısızlık tahmini yapmışlardır. Toplam 20 finansal oranın kullanıldı̆̆ çalışmada yapay sinir ağları modeli ile destek vektör makineleri ve çok boyutlu istatistiksel modellerin tahmin gücü karşılaştırılmıştır. Çalışma sonucunda, çok katmanlı yapay sinir ağları modelinin diğer modellere göre daha başarılı tahminde bulunduğu tespit edilmiştir.

Largani vd. (2012), İran'da Tahran Menkul Kıymetler Borsası'nda faaliyet gösteren firmalar üzerinde yaptıkları çalışma ile işletmelerde iflas tahmininde yapay sinir ağları modelinin kullanımını araştırmışlardır. Çalışma sonucunda finansal oranları kullanarak geliştirdikleri yapay sinir ağları modelinin iflas eden işletmeleri \%82, iflas etmeyen işletmeleri ise \%93 oranında 
doğru sınıflandırdığını tespit etmişlerdir. Dolayısıyla yapay sinir ağı modelinin iflas tahmini için kullanılabilir bir model olduğu sonucuna ulaşmışladır.

Altunöz (2013), bankaların finansal başarısızlığını yapay sinir ağları modeli ile tahmin etmeye çalışmıştır. Bu kapsamda Türkiye'de faaliyet gösteren bankalardan TMSF'ye devrolunan bankalar başarısız olarak belirlenmiş ve bağımsız değişken olarak ise yine bu bankalara ait finansal oranlar kullanılmıştır. Çalışma sonunda yapay sinir ağları ile oluşturduğu modelin 1 yıl ve 2 yı öncesinden yüksek oranda finansal başarısızlığı doğru tahmin ettiği sonucuna ulaşmıştır.

Civan ve Dayı (2013), sağlık işletmelerinde finansal başarısızlık tahmini yaparak Altman Z-skoru ve yapay sinir ağları ile geliştirdikleri modelleri karşılaştırmışlardır. Çalışmada 2008-2012 yıllarına ait Zonguldak Kamu Hastaneleri Birliği'ne bağlı sağlık işletmeleri veri seti olarak belirlenmiş olup bağımsız değişken olarak bu işletmelere ait finansal tablolardan elde edilen finansal oranlar kullanıımıştır. Çalışma sonucunda yapay sinir ağları modelinin finansal başarısızlık tahmininde daha doğru sonuçlar verdiğini gözlemlemişlerdir.

Yapılan çalışmalardan da görüleceği üzere, yapay sinir ağlarının kullanıldığı finansal başarısızlık tahmin çalışmalarının tamamında bağımsız değişken olarak mali tablolardan elde edilen finansal oranlar kullanıımıştır. Dolayısıyla yapılan literatür taraması da dikkate alınarak çalışmamızda da yapay sinir ağları ile finansal başarısızlık tahmin modeli oluşturulurken bağımsız değişken olarak, belirlediğimiz örneklemde yer alan işletmelerin mali tablolarından elde edilmiş finansal oranlardan yararlanılacaktır.

\section{BORSA ISTANBUL'DA IŞLEM GÖREN FIRMALAR ÜZERINE BIRR UYGULAMA}

Bu çalışmanın amacı, yapay zekâ teknolojilerinden olan yapay sinir ağları modeli kullanılarak işletmeleri finansal başarısızlığa düşmeden önce uyaracak bir erken uyarı modeli geliştirmektir. Yaşanması muhtemel bir finansal başarısızlık durumunun öngörülmesiyle, işletme sahip ve yöneticilerine zamanında müdahale fırsatı sağlanmış ve bu sayede işletmenin faaliyetlerini durduracak hatta iflasa sürükleyecek bir finansal başarısızlık yaşanmadan işletmelerini kurtarma imkânı olacaktır.

Çalışmada yapay sinir ağları ile geliştirilecek öngörü modelinde işletmelere ait finansal tablolardan elde edilen verilerle oluşturulan finansal oranlar kullanılacaktır. Çalışmamızda örneklem sayısını geniş tutmak adına sektörel bir ayırım yapılmamıştır. Ancak yine de işletmeler arasından özellikle holdingler, finansal kuruluşlar ve sigortacılık sektöründe faaliyette bulunan işletmeler farklı finansal özellik göstermelerinden dolayı örneklem dışında tutulmuştur. Ayrıca yeni kurulmuş işletmeler de çalışma kapsamına alınmamıştır. Zira yeni kurulmuş işletmeler finansal başarısızığa uğrayacaklarının izlenimini taşısalar da bu durum yeni kurulmuş işletmelerin bir özelliği olarak değerlendirilmiş ve çalışma kapsamına alınmamıştır.

Çalışmada, 2008-2013 yılları arasında faaliyet gösteren ve BiST'te işlem gören işletmeler örnekleme dâhil edilmiş ve bu kapsamda 72'si finansal başarısız, 72'i başarılı olmak üzere toplam 144 işletmeden oluşan bir örneklem belirlenmiştir. Bağımsız değişkenlere ait veriler ise bu işletmelerin Kamuyu Aydınlatma Platformu (KAP) www.kap.org.tr adresinde yayınlanan bağımsız denetimden geçmiş yıllık finansal durum tabloları ve kapsamlı gelir tablolarından elde edilmiştir. Örneklem seçiminde başarısız ve başarıı işletmelerin sayısının eşit sayıda belirlenmesinin nedeni; yapay sinir ağlarının en iyi öğrenmeyi gerçekleştirebilmeleri için, eğitim verileri içindeki değişik durumların eşit olarak temsil edilmesi gerekliliğindendir. Ayrıca belirlenen örneklem eğitim ve test/kontrol seti olmak üzere iki alt kümeye ayrılmıştır. Eğitim seti; yapay sinir ağlarının eğitilmesinde kullanılan bir alt kümedir. Test/kontrol seti ise, ağın karmaşık ilişkileri öğrenirken görmediği bir alt küme olup ağın genelleştirme yeteneğinin ölçülmesinde kullanılır. Bu kapsamda çalışmamızda, 144 işletmeden oluşan toplam örneklem setimiz 96 eğitim seti (48 başarısız, 48 başarılı) ve 48 test/kontrol seti (24 başarısız, 24 başarılı) olmak üzere iki alt kümeye ayrılmıştır.

Çalışmada geliştirilecek olan model için farklı yıllara ait işletme verilerinin kullanılması, enflasyon etkisinin ihmal edildiğini akla getirmektedir. Ancak bağımsız değişken olarak işletme finansal tablolarından elde edilen finansal oranların kullanılması sonucu bu etkinin ortadan kalktığı varsayılmıştır. Ayrıca, finansal oranların kullanılması, işletme büyüklüğü ve sektör farklııkları nedeniyle ortaya çıkabilecek olası sorunların da kontrol altına alınmasını ve bu faktörlerin etkilerinin de en aza indirilmesini sağlamaktadır.

Çalışmada başarıı ve başarısız işletmelerin eşit sayıda belirlenmesinin temel nedeni, yapay zekâ teknolojileri ile geliştirilecek olan modellerin en iyi öğrenmeyi gerçekleştirilebilmesi için finansal açıdan başarısız ve başarılı gibi farklı durumların eşit olarak temsil edilmesi gerekliliğidir.

Çalışmada başarılı ve başarısız işletmeler belirlenirken belirli bir yıl itibariyle yeterli sayıda işletme bulunmadığından ve finansal başarısızlık tahmin çalışmalarında sıklıkla karşılaşılan bir durum olduğundan dolayı farklı yılların verileri kullanılmıştır. Başarısızlık başlangıç yılı olarak; iki yıl ve daha fazla üst üste zarar eden işletmeler için zararın ikinci yılı, iflas eden işletmeler için iflas ettikleri yıl, işlem sırası kapanan işletmeler için işlem sırasının kapandığı yıl, aktif büyüklüğü ve özkaynakları bir önceki yıla göre \%10 azalan işletmeler için azalışın gerçekleştiği yıl, gözaltı piyasasında olan işletmeler için ise gözaltı piyasasına 
alındıkları yıl başarısızlık başlangıç yılı olarak kabul edilmiştir. Bu kapsamda bir yıl zarar etmiş olmasına rağmen bir sonraki yıl tekrar kâr eden işletmeler, diğer bir ifadeyle iki yıl üst üste zarar etmeyen işletmeler başarısız olarak değerlendirilmemiştir.

Çalışmada geliştirilen yapay sinir ağı modeli MATLAB programından yararlanılarak geliştirilmiştir. Program özellikle mühendislik alanında sıklıkla kullanıımakla birlikte sosyal bilimler alanında da gittikçe artan bir şekilde kullanılmaktadır.

\subsection{Uygulamada Kullanılan Bağımsız Değişkenler}

Bugüne kadar yapılan finansal başarısızlık tahmin çalışmalarının çoğunda, bağımsız değişken olarak finansal tablolardan elde edilen finansal oranların kullanıldığı görülmektedir. Esasen işletmelerin finansal durumlarını değerlendirebilmek için teorik olarak çok sayıda finansal oran hesaplanmakla birlikte literatürde önemli kabul edilen ve yaygın olarak kullanılan oranlar çalışmanın bağımsız değişkenlerini oluşturacak olan finansal oranlar olarak seçilmektedir. Dolayısıyla bu çalışmada da bağımsız değişken olarak işletmelere ait finansal tablolardan elde edilen, literatürde üzerinde birleşilen ve önemli kabul edilen finansal oranlar seçilmiş ve kullanılmıştır. Belirlenen 20 finansal oran, 4 temel grupta sınıflandırılarak Excel programı yardımıyla hesaplanmıştır.

Söz konusu oranlar Tablo 2'de verilmiş olup, bu oranlar işletmelerin 12 aylık finansal tablolarından elde edilen veriler yardımıyla hesaplanmıştır.

Tablo 2: Bağımsız Değişken Olarak Kullanılan Finansal Oranlar

\begin{tabular}{|c|c|}
\hline \multicolumn{2}{|c|}{ FINANSAL ORANLAR } \\
\hline \multicolumn{2}{|c|}{ Likidite Oranları } \\
\hline $\mathbf{X}_{1}$ & Cari Oran \\
\hline $\mathrm{X}_{2}$ & Likidite (Asit-Test) Oranı \\
\hline$x_{3}$ & Nakit Oranı \\
\hline \multicolumn{2}{|c|}{ Finansal Yapı Oranları } \\
\hline $\mathrm{X}_{4}$ & Finansal Kaldıraç Oranı \\
\hline$X_{5}$ & Kısa Vadeli Yabancı Kaynakların Toplam Kaynaklara Oranı \\
\hline$X_{6}$ & Uzun Vadeli Yabancı Kaynakların Toplam Kaynaklara Oranı \\
\hline$x_{7}$ & Uzun Vadeli Yabancı Kaynakların Devamlı Sermayeye Oranı \\
\hline $\mathrm{X}_{8}$ & Duran Varlıkların Özkaynaklara Oranı \\
\hline$X_{9}$ & Dönen Varlıkların Toplam Varlıklara Oranı \\
\hline \multicolumn{2}{|c|}{ Faaliyet Oranları } \\
\hline$X_{10}$ & Stok Devir Hızı \\
\hline$X_{11}$ & Alacak Devir Hızı \\
\hline$X_{12}$ & Çalışma Sermayesi Devir Hızı \\
\hline $\mathbf{X}_{13}$ & Duran Varlık Devir Hızı \\
\hline$X_{14}$ & Özkaynak Devir Hızı \\
\hline$X_{15}$ & Aktif Devir Hızı \\
\hline \multicolumn{2}{|c|}{ Kârlılık Oranları } \\
\hline$X_{16}$ & Özkaynağın Kârlılı̆ıı Oranı (Mali Rantabilite) \\
\hline$X_{17}$ & Faiz ve Vergi Öncesi Kârın Toplam Kaynaklara Oranı (Ekonomik Rantabilite) \\
\hline $\mathrm{X}_{18}$ & Toplam Varlıkların Kârııı̆ı Oranı \\
\hline$X_{19}$ & Brüt Kâr Marjı \\
\hline$X_{20}$ & Net Kâr Marjı \\
\hline
\end{tabular}

\subsection{Modelin Geliştirilmesi}

Öncelikle modelin oluşturulabilmesi için yapay sinir ağının mimarisi, öğrenme kuralı ve hata hesaplama oranı, girdi ve çıktı katmanı ile gizli katmanların sayısı, momentum terimi, aktivasyon fonksiyonu ve öğrenme adımı gibi parametrelerin belirlenmesi gerekir. Ancak yapay sinir ağı modellerinin geliştirilmesinde kullanılacak herhangi bir metodoloji olmadığı için, uygun parametrelerin belirlenmesinde deneme-yanılma yöntemi kullanılmakta ve çok sayıda test yapılmaktadır. Çalışmamızda da bu kapsamda uygun mimarinin belirlenerek başarılı bir model geliştirilmesi için ilgili parametrelerin çok değişik kombinasyonları kullanılarak çok sayıda model geliştirilmiş ve gerek eğitim seti üzerinde gerekse de test seti üzerinde en iyi performansı gösteren ağ belirlenmiştir. Ağın eğitimi için başarısızlıktan bir yıl önceki veriler kullanıımıştır. 
Yapay sinir ağı öğrenmesini kolaylaştırmak, eğitim algoritmasının gereksinimlerini karşılamak ve hesaplama problemlerinden kaçınmak için tek düze veriler oluşturmak amacıyla verilerin ön işleme tabi tutulması tavsiye edilmektedir (Torun, 2007; 94). Bu nedenle çalışmamızda da veriler ön işleme tabi tutulmuştur. Ön işlem olarak bütün değerler 1'den küçük olacak şekilde (en büyügü 1 olmak üzere) belirlenen bir katsayıya bölünerek normalize edilmiştir. Ön işlem sonucu diğer verileri çok anlamsız ve küçük değerlere dönüştürecek olan bazı işletmelere ait veriler ise dikkate alınmamıştır.

Çalışmamız kapsamında deneme-yanılma yöntemine göre çok sayıda model oluşturulduktan sonra belirlenen en uygun mimariye sahip ağın parametreleri Tablo 3'te belirtilmiştir.

Tablo 3: En İyi Performansa Sahip Ağın Parametreleri

\begin{tabular}{ll}
\hline Ağın Türü & Çok Katmanlı Illeri Beslemeli \\
\hline Ağın Algoritması & Geri Yayııım \\
\hline Öğrenme Türü & Danışmanlı Öğrenme \\
\hline Girdi Katmanındaki Nöron Sayısı & 20 \\
\hline Gizli Katman Sayısı & 5 \\
\hline Çıktı Katmanındaki Nöron Sayısı & 1 \\
\hline Momentum Katsayısı & 0,80 \\
\hline Öğrenme Oranı & 0,015 \\
\hline Öğrenme Adımı & 50.000 \\
\hline Transfer Fonksiyonu & Pürelin, Tanjant ve Logistic Sigmoid \\
\hline
\end{tabular}

Çok katmanlı ileri beslemeli ve geri yayılım algoritmasına sahip ağın mimarisi 1 girdi katmanı, 5 gizli katman ve 1 de çıktı katmanından oluşmuştur. Girdi katmanında 20 (20 adet bağımsız girdi değişkenine karşılık olarak), gizli katmanlarda ise sırasıyla 18, 14, 10, 8 ve 5, çıktı katmanında ise 1 ( 2 adet bağımlı çıktı değerine karşılık olarak) nöron bulunmaktadır. Girdi katmanındaki nöronlarda aktivasyon fonksiyonu olarak pürelin, diğer katmanlarda ise tanjant sigmoid ve logistic sigmoid fonksiyonları kullanılmıştır. Bu çalışmada geliştirilen en iyi performansa sahip yapay sinir ağının mimarisi ise Şekil 1'de görüldüğü gibidir:

Figür 1: En İyi Performansa Sahip Ağın Mimarisi

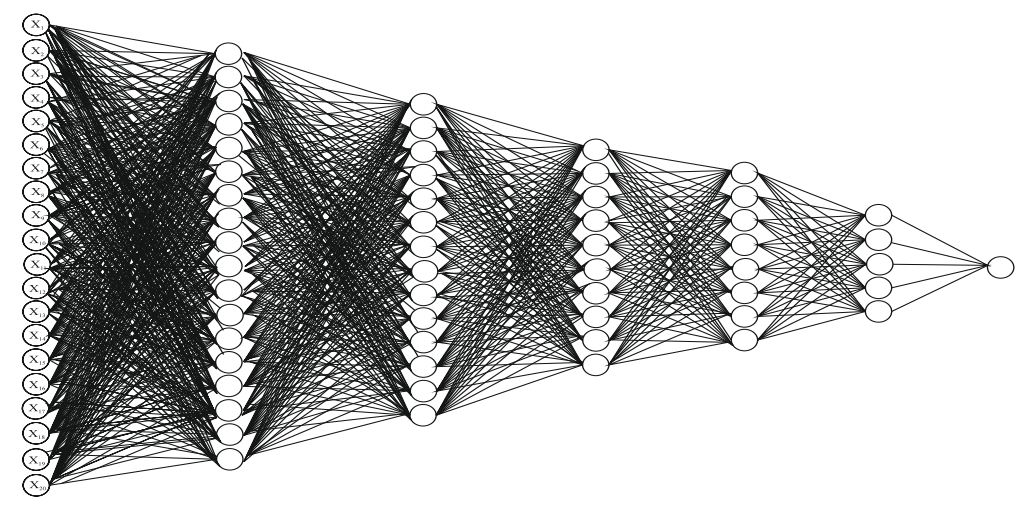

En uygun parametrelerle eğitilen ağdan, test setindeki işletmelere ait finansal oranlardan elde edilen verilerle karşıllaştırmak üzere çıktılar elde edilmiştir. Elde edilen yapay sinir ağı çıktıları yanlış sınıflandırma maliyetlerinin eşit olduğu varsayımı altında, "0,50" kopuş değeri esas alınarak tahmin gruplarına ayrılmıştır. Bu kapsamda, yazııımdan elde edilen yapay sinir ağı çıktısı "0,50" den büyük olan işletmeler "başarıı”, küçük olan işletmeler ise "başarısız" olarak gruplandırılmıştır. Daha sonra ise veriler programa sunulmadan önce belirli kriterlere göre finansal başarı durumu belirlenen işletmeler yapay sinir ağı çıktısına göre yapılan gruplandırmayla karşılaştııılarak yapay sinir ağlarıyla oluşturulan modelin finansal başarısızlık tahmin performansı ölçülmüştür.

Çalışmamızda geliştirdiğimiz en iyi parametrelerle eğitilen yapay sinir ağının eğitim aracı Şekil 2'de, öğrenme grafiği ise Şekil 3'teki gibidir: 


\section{Figür 2: YSA'nın Eğitim Aracı}

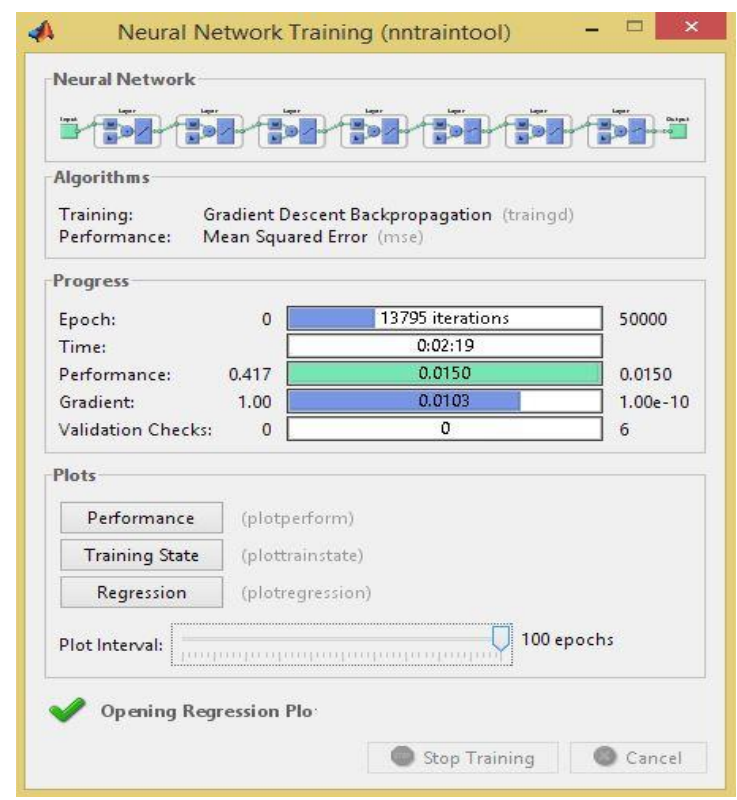

Figür 3: YSA'nın Öğrenme Grafiği

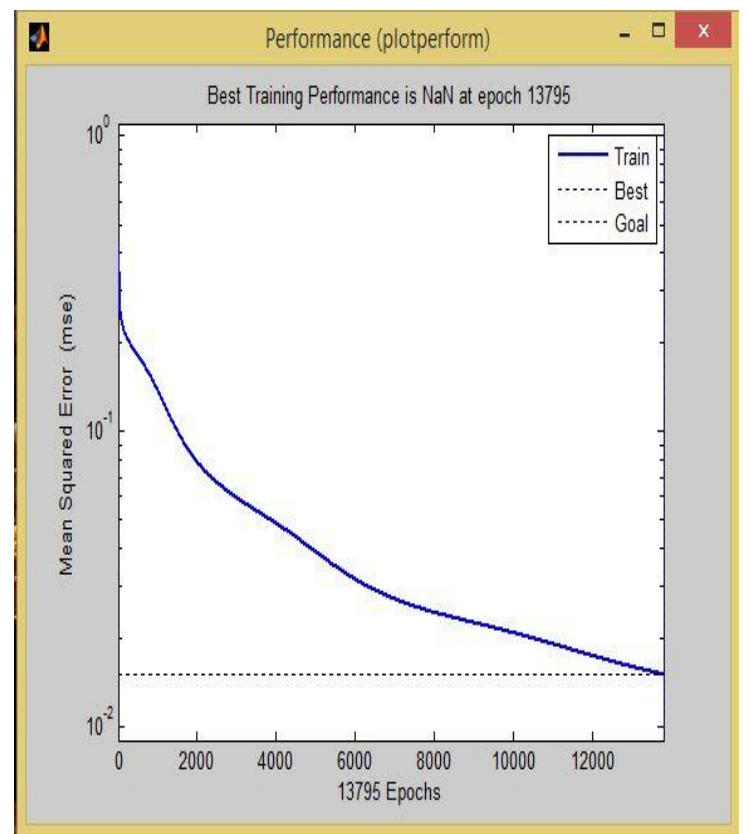




\section{BULGULAR VE DEĞERLENDIRME}

Yapay sinir ağı eğitim verilerindeki hatalar sıfırlanıncaya kadar eğitimi sürdürmektedir. Bu yüzden yapay sinir ağının doğru sınıflandırma oranı eğitim seti üzerinden değil test seti üzerindeki sonuçlara göre yapılmıştır. Test setinde yer alan işletmeler için yapay sinir ağı çıktıları ve tahminler Tablo 4'te verilmiştir.

\section{Tablo 4: YSA Modelinin Sonuçları ve Tahminleri}

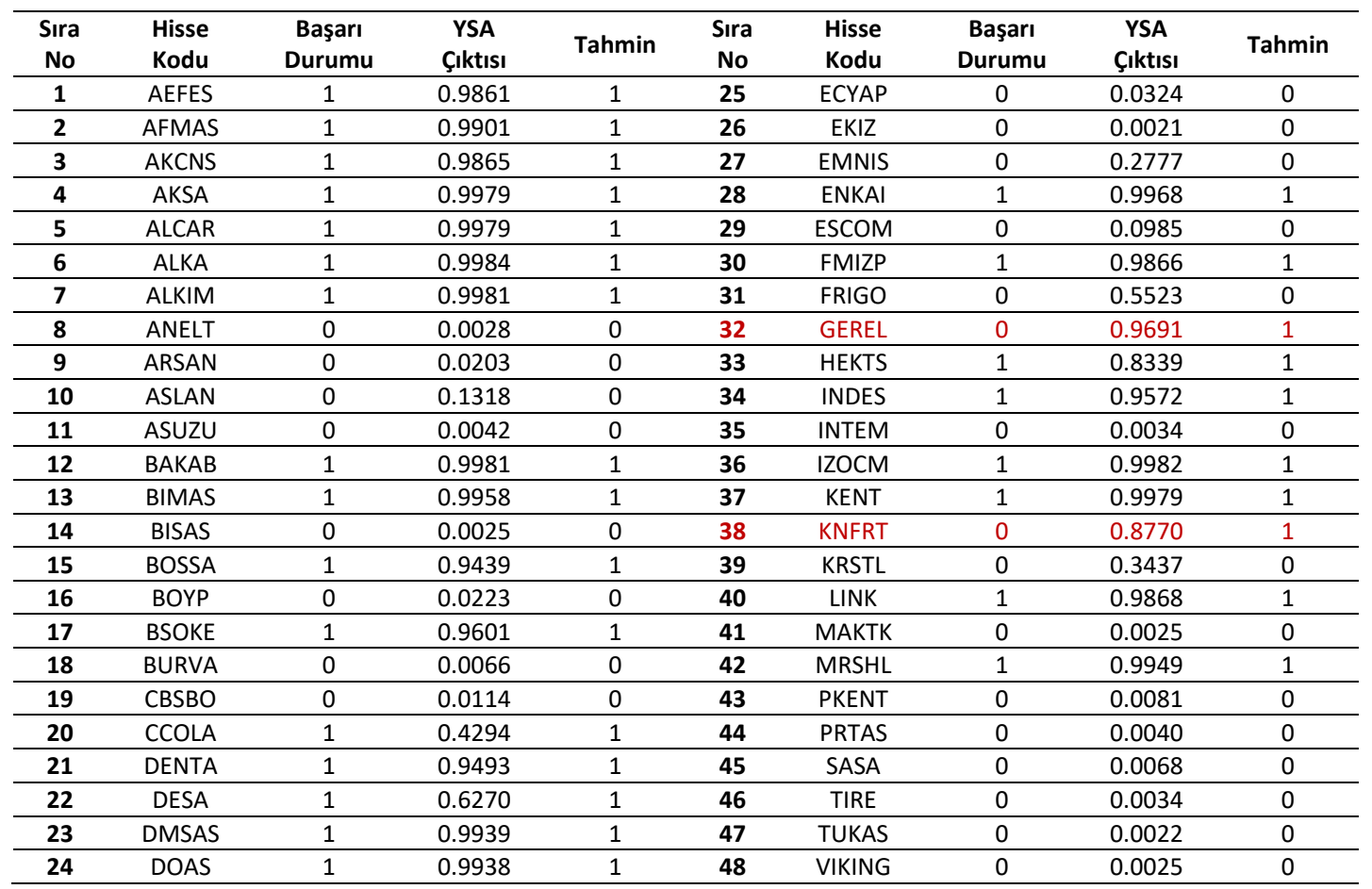

Tabloya göre GEREL ve KNFRT hisse kodlarına sahip işletmeler için gerçek durumla yapay sinir ağları çıktısına göre yapılan tahmin eşleşmemiştir. Diğer işletmeler için ise geliştirilen modelin doğru sınıflandırma yaptığı ve gerçek durumla ve yapay sinir ağları çıktısına göre yapılan tahminlerin eşleştiği görülmektedir.

İşletmelerdeki finansal başarısızlığın bir yıl öncesinden tahmin edilmesine yönelik olarak geliştirilen yapay sinir ağları modelinin eğitim seti üzerindeki sonuçlarının test seti üzerinden test edilmesiyle elde edilen sonuçların performansı ise Tablo 5'te belirtilmiştir.

Tablo 5: YSA'nın Test Seti Üzerindeki Doğru Sınıflandırma Performansı

\begin{tabular}{cccc}
\hline & \multirow{2}{*}{ Gerçek Grup } & \multicolumn{2}{c}{ Tahmin Edilen Grup } \\
& & Başarısız & Başarılı \\
\hline Başarısız & 24 & 22 & 0 \\
\hline Başarııı & 24 & 2 & 24 \\
\hline \multicolumn{5}{c}{ Toplam Doğru Sınıflandırma Oranı $=(22+24) / 48=\% 95,83$} \\
\hline
\end{tabular}

Tabloya göre yapay sinir ağının test setindeki 24 başarısız işletmenin 22'sini $(\% 91,66)$ ve 24 başarılı işletmenin ise 24 'ünü (\%100) doğru olarak sınıflandırdığı görülmektedir. Diğer bir ifadeyle, geliştirilen yapay sinir ağı modeli yanlış tahminle 24 başarısı işletmeden 2'sini başarılı olarak sınıflandırırken; başarılı işletmelerin ise tamamını doğru olarak sınıflandırmıştır. Bu kapsamda yapay sinir ağının neden olduğu Tip I hata oranı \%8,33 iken Tip II hata oranı ise 0'dır. Netice olarak yapay sinir ağı modelinin toplam doğru sınıflandırma oranı \%95,83 olarak gerçekleşmiştir. Bu da yapay sinir ağıyla finansal başarısılıktan bir yıl öncesi için geliştirilen modelin oldukça iyi bir sınıflandırma yaptığını göstermektedir.

\section{SONUÇ}

Temel amacı kâr elde etmek olan ve teorik olarak faaliyetlerini sonsuza kadar sürdürecekleri varsayılarak sınırsız ömrü olduğu kabul edilen işletmeler bu hayat seyirleri içerisinde finansal başarısızlıkla karşı karşıya kalabilmektedirler. Bu başarısızlık, geçici nedenlerle mali yükümlülüklerin karşılanamaması olabileceği gibi işletme varlıklarının tasfiye edilmesiyle 
iflasa kadar uzanan bir durum da olabilir. İşletmelerin finansal başarısızlığa uğramaları sadece kendi paydaşlarına değil aynı zamanda ülke ekonomilerine de ciddi maliyetler yüklemektedir. Zira bir ülke ekonomisinde başarısız işletmelerin sayısındaki artış, istihdam ve refah düzeyi ile ilgili olumsuz sonuçlara neden olacaktır. Dolayısıyla bireysel ve sosyoekonomik etkilere sahip finansal başarısızlığın öngörülerek doğru olarak tahmin edilebilmesi hem makro hem de mikro düzeyde önem arz etmektedir. Bu kapsamda finansal başarısızlık çalışmalarının son yıllarda finans alanının önemli araştırma konularından biri olduğu ve bu konuda çok sayıda araştırma yapıldığı görülmektedir. Bu yapılan çalışmalarda tek değişkenli modellerden çok değişkenli istatistiki yöntemlere ve yapay zekâ uygulamalarına kadar çok farklı yöntemler kullanılmıştır. Ancak her koşul ve ortamda kullanılabilecek hatasız bir tahmin yöntemi ve öngörü modelinin olmamasından dolayı, farklı verilerle ve farklı yöntemlerle uygun model bulma arayışının devam etmesine sebep olmaktadır. Bu nedenle bu çalışmada da literatürde farklı çalışmalarda kullanılan 20 finansal oran seçilerek yapay zekâ modellerinden olan yapay sinir ağları ile bir tahmin modeli geliştirilmiştir.

Finansal başarısızlık tahmin çalışmalarında en fazla kullanılan çok değişkenli istatistiki yöntem çok değişkenli diskriminant analizleri olmakla birlikte bu yöntem ilk defa Altman (1968) tarafından söz konusu çalışmada geliştirilen Z-skor modeli adıyla kullanılmıştır. Modelde 5 farklı finansal oran kullanılarak gruplar arası sınıflandırma yapılmıştır. Bu çalışmada yaygın olarak kullanılan Altman'ın Z-skor modeli yerine yapay sinir ağları modelinin tercih edilmesinin nedeni yapay sinir ağlarının tek değişkenli ve çok değişkenli istatistiksel modeler gibi varsayımlara gereksinim duymadan, çok sayıda değişken içeren ve karmaşık problemlerin çözümünde daha başarılı sınıflandırma yapabilmesi etkili olmuştur. Yapay sinir ağları modeli olarak ise çok katmanlı ileri beslemeli ve geri yayılım algoritmasına sahip bir sinir ağı tercih edilmiştir.

Çalışmada işletmelerdeki finansal başarısızlığın 1 yıl öncesinden tahmin edilebilmesi için geliştirilen yapay sinir ağı modelinin test setindeki 24 başarısız işletmenin 22'sini (\%91,66) ve 24 başarılı işletmenin ise 24 'ünü (\%100) doğru olarak sınıflandırdığı görülmüştür. Model başarılı işletmelerin doğru sınıflandırılmasında sıfır hatayla \%100 doğrulukla sınıflandırma yaparken; başarısız işletmelerden sadece 2'sini başarılı olarak sınıflandırmıştır. Toplamda ise yapay sinir ağı modelinin doğru sınıflandırma oranı \%95,83 olarak gerçekleşmiştir.

Çalışmada elde edilen bulgular neticesinde yapay sinir ağlarının işletmelerdeki finansal başarısızlığın öngörülmesinde yüksek derecede doğru sınıflandırma yaparak etkili bir tahmin modeli olduğu sonucuna varılmıştır. Bu nedenle, işletme sahip, ortak ve yöneticileri ile işletmeye kredi sağlayan kişi ve kuruluşların, potansiyel yatırımcıların ve devletin finansal başarısızlığın tahmininde yapay sinir ağları teknolojilerinden yararlanmaları hem hızlı hem de yüksek oranda doğru karar alabilmelerine imkân tanıyacaktır.

Yapay sinir ağlarının tüm bu olumlu yönlerine ve başarılı sonuçlarına rağmen unutulmaması gereken bir nokta vardır. Yapay sinir ağları modelinin en önemli dezavantajlarından biri ağın kara kutu mantığında hareket etmesidir. Yani elde edilen modele ilişkin katsayıların ağın içindeki ağırlıklarının henüz yorumlanamaması ve çok sayıda deneme-yanılma yöntemiyle uygun parametrelerin belirlenmesi sonucu üretilen bilgi ağın içinde saklı kalmaktadır. Bu konuda yapılan çalışmalar halen devam etmekte olup, bundan sonraki çalışmalarda üretilen bilginin de ağın dışına çıkarılarak kara kutu mantığından kurtulan modellerin geliştirilmesiyle yapay sinir ağları ile finansal başarısızlık tahmininin daha iyi sonuçlar vereceği düşünülmektedir.

\section{KAYNAKÇA}

Akgüç, Ö. (2010). Finansal Yönetim (8. bs.). İstanbul: Avcıol Basımevi.

Akkaya, G. C., Demireli, E. ve Yakut, Ü. H. (2009). İşletmelerde Finansal Başarısızık Tahminlemesi: Yapay Sinir Ağları Modeli ile iMKB Üzerine Bir Uygulama, Eskişehir Osmangazi Üniversitesi Sosyal Bilimler Dergisi, 10(2), 187-216.

Aktaş, R., Doğanay, M. M. ve Yıldız, B. (2003). Mali Başarısızığın Öngörülmesi: İstatistiksel Yöntemler ve Yapay Sinir Ağı Karşılaştırması, Ankara Üniversitesi SBF Dergisi, 58(4), 1-24.

Alavala, C. R. (2008). Fuzzy Logic and Neural Networks: Basic Concepts\&Applications. India: New Age International Limited, Publishers.

Altman, E. (1968). Financial Ratios, Discriminant Analysis and The Prediction of Corporate Bankruptcy, The Journal of Finance, 23(4), 589609.

Altman, E. I., Haldeman, R. G. ve Narayanan P. (1977). Zeta Analysis, Journal of Banking and Finance,1, 29-54.

Altunöz, U. (2013). Bankaların Finansal Başarısızlıklarının Yapay Sinir Ağları Modeli Çerçevesinde Tahmin Edilebilirliği, Dokuz Eylül iktisadi ve Idari Bilimler Fakültesi Dergisi, 28(2), 189-217.

Atiya, A. F. (2001). Bankruptcy Prediction for Credit Risk Using Neural Networks: A Survey and New Results, IEEE Transactions on Neural Networks, 12(4), 929-935.

Beaver, W. H. (1966). Financial Ratios as Predictors of Failure, Journal of Accounting Research, 4, Empirical Research in Accounting: Selected Studies, 71-11. 
Benli, K. Y. (2005). Bankalarda Mali Başarısızlığın Öngörülmesi: Lojistik Regresyon ve Yapay Sinir Ağı Karşılaştırması, Gazi Üniversitesi Endüstriyel Sanatlar Eğitim Fakültesi Dergisi, 16, 31-46.

Boyacıoğlu, M. A., Kara, Y. ve Baykan, Ö. K. (2009). Predicting Bank Financial Failures Using Neural Networks, Support Vector Machines and Multivariate Statistical Methods: A Comparative Analysis in The Sample of Savings Deposit Insurance Fund (SDIF) Transferred Banks in Turkey, Expert Systems with Applications 36, 3355-3366.

Chakraborty, S. ve Sharma, S. K. (2007). Prediction of Corporate Financial Health by Artificial Neural Network, International Journal of Electronic Finance, 1(4), 442-459.

Chen, J., Marshall, B. R., Zhang, J. ve Ganesh, S. (2006). Financial Distress Prediction in China, Review of Pacific Basin Financial Markets and Policies, 9(02), 3117-336.

Civan, M. ve Dayı, F. (2013). Altman Z Skoru ve Yapay Sinir Ağı Modeli ille Sağlık İşletmelerinde Finansal Başarısızlık Tahmini, Akademik Bakış Dergisi, 39, 1-14.

Dambolena, I. G. ve Khoury, S. J. (1980). Ratio Stability and Corporate Failure, The Journal of Finance, 35(4), 1017-1026.

Efe, Ö. ve Kaynak, O. (2000). Yapay Sinir Ağları ve Uygulamaları. İstanbul: Boğaziçi Üniversitesi Yayınları.

Elam, R. (1975). The Effect of Lease Data on the Predictive Ability of Financial Ratios, The Accounting Review, 50(1), 25-43.

Fausett, L. (1994). Fundamentals of Neural Networks: Architectures, Algorithms and Applications. New Jersey, USA: Prentice-Hall International.

Gitman, L. J. ve Chad, Z. J. (2011). Principles of Managerial Finance (13th Edition). USA: Prentice Hall.

Gritta, R. C., Davalos, S., Chow, G. ve Wang, H. (2000). Forecasting Small Air Carrier Bankruptcies Using A Neural Network Approach: A Preliminary Analysis, Journal of Financial Management and Analysis, 13(1), 44-49.

Jo, H., Han, I. ve Lee, H. (1997). Bankruptcy Prediction Using Case-Based Reasoning, Neural Networks and Discriminant Analysis, Expert Systems with Applications, 13(2), 97-108.

Keskin, Y. (2002). İşletmelerde Finansal Başarısızlığın Tahmini, Çok Boyutlu Model Önerisi ve Uygulaması, Yayımlanmamış Doktora Tezi, Hacettpe Üniversitesi, Ankara.

Küçükkocaoğlu, G., Keskin, B. Y. ve Küçüksözen, C. (2009). Finansal Bilgi Manipülasyonunun Tespitinde Yapay Sinir Ağı Modelinin Kullanımı, IMKB Dergisi, 9(36), 1-23.

Largani, M. S., Lakelaye, M. P., Kaviani, M. ve Largani, N. S. (2012). Bankruptcy Prediction Using Artificial Neural Networks Evidences From IRAN Stock Exchange, ARPN Journal of Science and Technology, 2(6)562-566.

Lippmann, R. P. (1987). An Introduction to Computing with Neural Nets, IEEE ASSP Magazine, 4(1), 4-22.

Moyer, C. R., McGuigan J. R., Rao, R. P. ve Kretlow, W. (2011). Contemporary Financial Management (12. Edition). South-Western, USA: South-Western Cengage Learning.

Nguyen, H. G. (2005). Using Neural Network in Predicting Corporate Failure, Journal of Social Sciences, 1(4), 199-202.

Norton, C. L. ve Smith, R. E. (1979). A Comparison of General Price Level and Historical Cost Financial Statements in thePrediction of Bankruptcy, The Accounting Review, 54(1), 72-87.

Odom, M. D. ve Sharda, R. (1990). A Neural Network Model for Bankruptcy Prediction, IJCNN International Joint Conference on Neural Networks, 2, 163-168.

Ohlson, J. A. (1980). Financial Ratios and The Probabilistic Prediction of Bankruptcy, Journal of Accounting Research, 18(11), $109-131$.

Özdemir, F. S., Choi, F. S. ve Bayazıtlı, E. (2012). Finansal Başarısızlık Tahminleri Yönüyle UFRS ve Bilginin İhtiyaca Uygunluğu, Mali Çözüm Dergisi, 112, 17-52.

Özdemir, F. (2011). Finansal Raporlama Sistemlerinin Bilginin ihtiyaca Uygunluğu Açısından Değerlendirilmesi: IMKB Şirketlerinde Finansal Başarısızlık Tahminleri Yönüyle Bir Uygulama, Yayımlanmamış Doktora Tezi, Ankara Üniversitesi, Ankara.

Öztemel, E. (2012). Yapay Sinir Ağları (3. Basım). İstanbul: Papatya Yayıncılık.

Pompe, P. P. M. ve Feelders, A. J. (1996). Artificial Intelligence in Economics and Management. P. Ein-Dor (Ed.). Using Machine Learning, Neural Networks and Statistics to Predict Corporate Bankruptcy: A Comparative Study (pp. 3-19). Kluwer Academic Publishers.

Raghupathi, W., Schkade, L. L. ve Raju, B. S. (1991). A Neural Network Application for Bankruptcy Prediction, Proceedings of the TwentyFourth Annual Hawaii International Conference on System Sciences: 8-11 Ocak 1991 - Hawaii, Vol. IV (147-155). IEEE Publishers.

Ravi, V. ve Pramodh, C. (2008). Threshold Accepting Trained Principal Component Neural Network and Feature Subset Selection: Application to Bankruptcy Prediction in Banks, Applied Soft Computing, 8(4), 1539-1548. 
Ross, S. A., Westerfield, R. W. ve Jaffle, J. (2008). Corporate Finance (Eight Edition). New York, USA: McGraw-Hill Irwin.

Tektaş, A. ve Karataş, A. (2004). Yapay Sinir Ağları ve Finans Alanına Uygulanması: Hisse Senedi Fiyat Tahminlemesi, Atatürk Üniversitesi, iktisadi ve idari Bilimler Dergisi, 18(3-4), 337-349.

Torun, T. (2007). Finansal Başarııızık Tahmininde Geleneksel Istatistiki Yöntemlerle Yapay Sinir Ağlarının Karşılaştııılması ve Sanayi işletmeleri Üzerine Bir Uygulama, Yayınlanmamış Doktora Tezi, Erciyes Üniversitesi, Kayseri.

Van-Frederikslust, R. A. I. (1978). Predictability of Corporate Failure: Models for Prediction of Corporate Failure and for Evalution of Debt Capacity. Leiden: Martinus Nijhoff Social Sciences Division.

Wilcox, J. W. (1971). A Simple Theory of Financial Ratios as Predictors of Failure, Journal of Accounting Research, 389-395.

Wu, D. D., Liang, L., ve Yang, Z. (2008). Analyzing The Financial Distress of Chinese Public Companies Using Probabilistic Neural Networks and Multivariate Discriminate Analysis, Socio-Economic Planning Sciences, 42(3), 206-220.

Yıldız, B. (1999). Finansal Başarııızı̆̆ın Öngörülmesinde Yapay Sinir Ağları Modelinin Kullanımı ve Ampirik Bir Çalışma, Yayımlanmamış Doktora Tezi, Dumlupınar Üniversitesi, Kütahya.

Yıldız, B. (2001). Prediction of Financial Failure with Artificial Neural Network Technology and An Emprical Application on Publicly Held Companies. ISE Review, 5(17), 47-62.

Yıldız, B. (2009). Finansal Analizde Yapay Zekâ. Ankara: Detay Yayıncılık.

Zhang, G., Patuwo, G. E. ve Hu, M. Y. (1998). Forecasting with Artificial Neural Networks: The State of the Arts, International Journal of Forecasting, 4(1), 35-62.

Zhang, G., Hu, M. Y, Patuwo, B. E. ve Indro, D. C. (1999). Artificial Neural Networks in Bankruptcy Prediction: General Framework and Cross-Validation Analysis, European Journal of Operational Research, 116, 16-32. 